\title{
South Africa's Multilateral Challenges in a Polypolar World
}

\section{Yolanda Kemp Spies}

It came as little surprise when post-apartheid South Africa (SA) adopted a foreign policy that prioritised multilateralism as a normative cornerstone of its international relations. ${ }^{1}$ The struggle against apartheid was a global effort and a cause that transcended the ideological divide of the Cold War. It united transnational civil society networks and official state representatives within the ambit of intergovernmental organisations (IGOs) to an extent that no other single issue on the global agenda had ever done. When the country's peaceful transition to democracy happened, the world not only lauded it - the world was also a stakeholder. ${ }^{2}$ The 'new' SA needed to be 'present and voting' within the community of nations, and multilateral fora offered the practical cum symbolic opportunities to do so.

The nascent foreign policy of democratic SA emerged as international relations (IR) scholars were chartering new waters - the end of apartheid coincided with the end of the bipolar Cold War. ${ }^{3}$ In a discipline traditionally concerned with systemic distribution of power, the nature and implications of post-Cold War polarity were of great significance. The immediate prognosis was one of uncontested unipolarity, to the extent that a scholar of note saluted the sole triumphant superpower of the world (or at least its associated politico-economic ideology) with a prediction of the "end of history". ${ }^{4}$ Scholars as well as statesmen were soon emphasising the advantages of multipolarity as a systemic balance to the hegemonic, neo-empire implications of a unipolar world.

From a 'global South' perspective, unipolarity represented more than the preponderance of a single hyperpower - it implied a global order in which the only pole of note continued to be the 'global North'. If anything, replacement of the

Yolanda Kemp Spies is a Senior Lecturer in the Department of Political Sciences at the University of Pretoria, and the manager of its Master of Diplomatic Studies programme. Email: yolanda.spies@up.ac.za ${ }^{1}$ Zondi, "Contributing the South African perspective", 27.

${ }^{2}$ Nelson Mandela referred to "the new South Africa which you helped to bring into being" when he delivered his maiden speech as South African President to the UN General Assembly on 3 October 1994. www.anc.org.za/ancdocs/speeches/un49th.html

${ }^{3} \mathrm{~A}$ possible causal link will not be explored in this paper.

${ }^{4}$ Fukuyama, "End of History". 
Cold War's ideological competition with economic rivalry simply intensified the struggle of the developing world against marginalisation. The systemic antidote would require not only the entrenchment of multipolarity, but indeed the transformation of global governance to counter the hegemonic abuse of multilateral institutions. SA's foreign policymakers embraced the transformative potential of multilateralism and, projecting the country's domestic democratic transition onto a global level, embarked on a crusade to achieve equitable, rule-based global governance.

Even though IR was infamously unable to predict the end of the Cold War (and one could argue, the nature of SA's transition!), the events mentioned thus far can all be accounted for by the traditional paradigms of the discipline. However, the unfolding world order and global power relations have subsequently proven to be decidedly more complex than the positivists have been able to explain. The reality of relationships among actors in the international system is so mercurial that Timothy Shaw, Andrew Cooper and Gregory Chin identify a challenge for "scholars to stretch conceptions of world order, multipolarity and interdependence". 5 Richard Haass refers to this "diffuse" new world order as "nonpolar": a world dominated not by one or two or even several states, but rather by numerous centres possessing and exercising various kinds of power. ${ }^{6}$

Preferring to describe the emerging global order as 'polypolar', the author will argue that the global system has post-modern features in the sense that the identities of the 'poles' are becoming fluid and transient. This has important implications for the multilateralism of SA, which has thus far resolutely anchored its foreign policy in a global South identity. The article will locate SA's evolving multilateralism within the new systemic ${ }^{7}$ (dis)order and explore the options and imperatives confronted by this African middle power.

\section{South Africa as a middle power}

In the heady first years of SA's democracy, the previously isolated country joined just about every IGO it could, assumed chairmanship of a significant number of them and quickly became a hub of global summits. ${ }^{8}$ Its embrace of multilateralism did not just manifest quantitatively. The ethical dimension of SA's foreign policy was buttressed by the political and economic stability that followed its democratic

\footnotetext{
${ }^{5}$ Shaw et al., "Emerging powers and Africa", 27.

${ }^{6}$ Haass, "Age of nonpolarity".

${ }^{7}$ The analysis will thus focus on the systemic level, but with the caveat that any comprehensive understanding of SA's foreign policy should be contextualised with due consideration for domestic variables, as well as psychoanalytical attention to aspects of agency at the individual foreign policymaker level.

${ }^{8}$ For discussion of the post-1994 inflation in SA's diplomatic relations, see Muller, "Current events in SA diplomacy"; Van der Westhuizen, "Global conference circuit"; and A. Nzo, Parliamentary briefing by the South African Minister of Foreign Affairs, Cape Town, 8 February 1999. http://www.info.gov.za/speeches/ 1999/99210_foreig99_10095.htm
} 
transition and was amplified by the global stature of an iconic president and the statesmanlike roles of the country's two other living Nobel Peace laureates. ${ }^{9}$ At the international level, the country enjoyed a unique reputation - that of having unilaterally disarmed its nuclear arsenal. The new government committed its diplomatic and military resources to international peace-brokering, with its bridgebuilding diplomacy stretching far beyond its borders in Africa, earning the country a reputation as norm entrepreneur. ${ }^{10}$

The country's predilection for multilateralism and its willingness to exert moral influence in multilateral fora ${ }^{11}$ ensured that it complied with the profile of a middle power. Eduard Jordaan ${ }^{12}$ argues that SA should in fact be identified more precisely as an emerging middle power, which would contrast its international role with those of traditional middle powers such as New Zealand, Canada and Sweden. These states have entrenched democracies, affluent societies with egalitarian socio-political dispensations and are not regionally distinct actors. In contrast, emerging middle powers such as SA, Brazil, Mexico, Turkey and Malaysia differ markedly from their traditional counterparts in that they have attained their status mostly after the end of the Cold War. They are new democracies, semiperipheral in the world economy and materially at the domestic level. They also pursue conspicuous regional agendas.

Jordaan's thesis complements the findings of theorists who analyse the diplomatic behaviour of developing states. Donald Puchala points out that the diplomacy of peripheral states is relatively more vocal, vigorous and even confrontational, with messages targeting international interlocutors as much as they are intended to impress a domestic constituency. ${ }^{13}$ For these states, diplomacy offers the most viable foreign policy instrument: in the absence of economic might and other capabilities that could be used as carrots and sticks, they have to rely disproportionately on diplomacy to impact international politics.

The semi-peripheral states that become middle powers thus superimpose their assertive diplomacy on the multilateralism for which the traditional 'good citizens' of the international system are renowned: they act as stabilizers of global order, play

\footnotetext{
${ }^{9}$ The other two being Archbishop Desmond Tutu and former President F.W. De Klerk. The fourth in the group and Africa's first Nobel Peace laureate, Chief Albert Luthuli, died in 1967.

${ }^{10}$ Among many other achievements, SA secured developing world support for the 1995 indefinite extension of the Nuclear Non-Proliferation Treaty and was a driver in the 1997 Ottawa Process on the banning of land mines, the 1998 adoption of the Rome Statute that established the International Criminal Court, and the formulation and adoption of the Millennium Development Goals in 2000. Geldenhuys, "SA as norm entrepreneur".

${ }^{11}$ As South Africa's Deputy Foreign Affairs Minister, Aziz Pahad emphasized in a speech to the South African Institute of International Affairs (SAIIA), Cape Town, in February 2007, "the importance of maintaining multilateralism has never been so pertinent... [it] remains the most effective and efficient system for addressing global problems. In history no other form of inter-state cooperation has delivered the same results as multilateralism." http://www.dfa.gov.za/docs/speeches/pahad.htm

${ }^{12}$ Jordaan, "Concept of a middle power".

${ }^{13}$ Puchala, "Third World thinking".
} 
activist roles in global governance and network with like-minded states and other actors in order to legitimize global public policy. However, as Jordaan contends, whereas traditional middle powers have a concessionary attitude to global reform, emerging middle powers have a reformist approach. ${ }^{14}$ This is undoubtedly because they face serious developmental challenges themselves. Their semi-peripheral position thus allows for them to act as intermediaries between the industrialised core and the resource rich periphery, as Chris Alden and Garth Le Pere ${ }^{15}$ note about SA - hence the latter's willingness to champion the cause of the global South through middle power activities.

\section{Championing the cause of the global South to transform global governance}

Ever since the global South started to crystallise into distinct diplomatic assemblages, ${ }^{16}$ the diplomatic action of these states has resembled a Lilliputian struggle against the hegemony of the world's industrialised powers. Their growing assertiveness during the latter half of the 20th century and their proclivity towards collective diplomatic strategy contributed to the groundswell in multilateralism quantitatively fuelled by the fact that they now comprise the vast majority of United Nations (UN) member states. This group is well aware that multilateral, rather than any other types of agreement establish the international regimes that organise the most salient aspects of contemporary interstate relations, in the absence of a supranational authority. ${ }^{17}$ The structure of global governance, however, is considered to be skewed in favour of the industrialised North, and thus an obstacle to equitable opportunities for development.

Newly democratic SA aligned itself with the global South just as the demise of the Cold War created space for a re-evaluation of global governance. ${ }^{18}$ The struggle against the political hegemony of apartheid would henceforth be replicated in the country's advocacy for redress of the democratic deficit at the global level, and as such, the driver of SA's multilateralism was initially essentially normative. During Nelson Mandela's presidency, this diplomatic quest was rhetorical rather than concrete, as the parameters of the country's foreign policy seemed nebulous. ${ }^{19}$ The pursuit of South-South solidarity became more articulated and

\footnotetext{
${ }^{14}$ Jordaan, "Concept of a middle power", 167.

${ }^{15}$ Alden and Le Pere, "South Africa in Africa", 147.

${ }^{16}$ Initiated by the formation of the first 'Third World' grouping, the Non-aligned Movement (NAM), during the 1950 s.

${ }^{17}$ Cooper et al., Global Governance and diplomacy, 2.

${ }^{18}$ In anticipation of the post-1994 democratic dispensation, Nelson Mandela outlined the ethical foundations of SA's future foreign policy in a 1993 article in Foreign Affairs, "South Africa's future foreign policy".

${ }^{19}$ Serrão and Bischoff ("Foreign policy ambiguity", 364) recall that SA's foreign policy was so riddled with inconsistencies that some commentators alleged the country had no foreign policy at all.
} 
institutionalised during the two consecutive presidential terms of Mandela's successor, Thabo Mbeki. Micro-managed by Mbeki himself, SA's multilateralism took on an ideological tenor. In an address to Parliament in June 2000, he extolled the virtue of the global 'have-nots' standing up to the 'haves as follows:

... the critical question of our time [is] how humanity should respond to the irreversible process of globalisation while addressing the fundamental challenges that face the bulk of humanity. These include poverty, underdevelopment, the growing North-South gap, racism and xenophobia, gender discrimination, ill health, violent conflicts and the threat to the environment.... Central to these processes must be the objective of reversing the marginalisation of Africa and the rest of the South, and therefore compensation for the reduction of national sovereignty by increasing the capacity of the South to impact on the system of global governance. ${ }^{20}$

Five years later, Mbeki reiterated this point when he addressed world leaders at the UN Millennium Review Summit. He decried the "widely disparate conditions of existence and interests among the Member States of the UN as well as the gross imbalance of power that define the relationship among these Member States" and stated bluntly that "the rich and powerful... use their power to perpetuate the power imbalance in the ordering of global affairs". ${ }^{21}$

Thus SA adopted the cause of representative global governance and set out on a campaign to transform the institutions where the global rules are made: inter alia the UN, the Bretton Woods institutions, and the World Trade Organisation (WTO). In the latter forum specifically, the Global South's insistence on linking international trade with people-centred, sustainable development produced various strategic South-South alliances. In the wake of the collapse of the Cancun Round, SA spearheaded the establishment of the India-Brazil-South Africa (IBSA) forum during September 2003. IBSA built on the combined leverage of these three leader states, straddling Asia, Latin America and Africa, and attracted much attention from analysts and policymakers alike. ${ }^{22}$

From the very beginning of his presidency, Mbeki was instrumental in efforts to add the economic concerns of the global South, such as debt, development aid and fair trade, to the agenda of the global North. ${ }^{23}$ This was most successful in relation to the G8 - the powerful core of industrialised countries that dominate the global economy. The informal North-South dialogue that Mbeki advanced was

\footnotetext{
${ }^{20}$ Speech by South African President Thabo Mbeki to the National Assembly on the occasion of the consideration of the budget vote of the Presidency, Cape Town, 13 June 2000, www.dfa.gov.za/docs/ speeches/mbeki.htm

${ }^{21}$ Address by South African President Thabo Mbeki at the UN Millennium Review Summit. New York, 15 September 2005. www.dfa.gov.za/docs/speeches/mbeki.htm

${ }^{22}$ See, for example, Francis Kornegay's (Will a BRIC fall on IBSA?) discussion.

${ }^{23}$ Shaw et al. ("Emerging powers and Africa", 37) illustrate his tenacious lobbying by pointing out that between 2000 and 2008, Mbeki attended every single G8 summit - one more than George W. Bush, the senior G8 leader!
} 
institutionalised when the G8 at its 2005 Gleneagles Summit formalised its annual deliberations with the so-called Outreach Five states, which comprised the IBSA trio in addition to China and Mexico. Under Mbeki's leadership, ${ }^{24}$ SA's multilateral championing of the global South's cause achieved its zenith, and nowhere more so than in the ambitious plan to pioneer an 'African Renaissance'. However, not all commentators are convinced that SA's foreign policy under Mbeki's guidance was, in fact, normative-driven or successful in its stated aims. Patrick Bond, in a highly critical analysis of the Mbeki government's global reform programme, accuses Mbeki of representing the global South in bad faith by wielding a shield of radical rhetoric and, behind it, embracing with enthusiasm the global establishment's neoliberal premises and institutions. ${ }^{25}$

\section{South Africa's multilateral commitment to Africa}

Bond's allegation that democratic SA has continued to exploit Africa by playing an economically aggressive "subimperial role", ${ }^{26}$ is something the post-apartheid government would be loathe to admit. The latter was at pains to reverse apartheid-SA's political alienation from the rest of the continent by emphasising its African identity at every diplomatic opportunity and demonstrating its commitment to underwrite pan-African aspirations. Thus former Foreign Minister Nkosazana Dlamini-Zuma assured the South African Parliament in February 2009 that as "part of creating a better Africa, we have ourselves contributed our own sons and daughters of our country to various positions both in continental structures as well as international organisations". ${ }^{27}$

The prioritisation of an African Agenda did, indeed, manifest in some of SA's most ambitious multilateral projects. According to Adam Habib, ${ }^{28}$ the goal was no less than total reconstruction of the continent' institutional architecture, buoyed by what Alden and Le Pere call "a revivalist form of the pan-Africanist ideology". 29 The establishment of the African Union (AU) in 2002, as successor to the

\footnotetext{
${ }^{24}$ Habib ("South Africa's foreign policy", 145-7) argues that Mbeki's personal impact on SA's multilateral profile is informed by the fact that he is an example of second generation nationalist leadership within the global South. These leaders, Habib explains, are "acutely aware of their countries' relative weakness and that their anti-colonial agendas will not materialise outside the transformation of the balance of power in the global order". They therefore display a combination of principle and pragmatism: in order to subvert the power relations of the international system, they not only have to understand the rules of the game, but also actively play by those rules until such time as they have opportunity to change it. This requires a calculated, sophisticated and very proactive approach, something at which Mbeki excelled.

${ }^{25}$ Bond, Talk Left, Walk Right, 4.

${ }^{26}$ Ibid, 296.

${ }^{27}$ Address by the South African Minister of Foreign Affairs during the State of the Nation Debate in Parliament: "A Better Africa and a Better World", Cape Town, 9 February 2009.

${ }^{28} \mathrm{Habib}$, "South Africa's foreign policy", 148.

${ }^{29}$ Alden and Le Pere, "South Africa in Africa", 145.
} 
discredited Organisation of African Unity (OAU), represented the most elaborate structural achievement of SA'n-driven multilateralism in Africa.

At the international level, SA used its middle power credentials to ensure that the African Agenda permeated the fora of global governance - and as its government would argue, with the express normative aim of lifting the continent out of its dire economic situation. Inter alia this resulted in the G8, at its Kananaskis Summit in 2002, committing to the objectives of a continental programme that Mbeki and the leaders of Nigeria and Senegal had engineered, the New Partnership for Africa's Development (NEPAD). The G8, in a dedicated Africa Action Plan, hailed NEPAD as "a bold and clear-sighted vision of Africa's development". 30 Three years later, at its Gleneagles Summit, the issue of poverty in Africa was accorded a key place on the G8's primary agenda. South African Foreign Minister Maite NkoanaMashabane unabashedly declared the government "proud of the progress we have registered" over a decade and a half of "aggressively put[ting] the case of the rejuvenation of Africa's economies and development on the tables of the Bretton Woods institutions and the UN.... Together with our fellow African brothers and sisters, we have promoted NEPAD through a sustained engagement with the G8 group of countries." 31

SA's rejection of unilateralism at the global level was mirrored in its denial of a hegemonic role at the continental level - at least in terms of its political relations. For at least the first decade and a half of the new democracy, its government seemed genuinely concerned that assertive leadership would be regarded by neighbouring states as predatory. It therefore played down any intimation of dominance by genuflecting to the collective will of the region. ${ }^{32}$ Ironically, SA's high-level visibility on the world stage, as it crusaded to transform global power relations on behalf of peripheral states, raised the spectre of its own pre-eminence in Africa. This was compounded by the obvious and massive asymmetry in its economic relations with the rest of the continent. Inevitably, it was drawn into a continental microcosm of global attempts to stave off unipolarity, as several 'poles' emerged in the form of aspiring continental leaders. ${ }^{33}$ Competition, even friction, with states such as Nigeria, Egypt, Libya and, in the sub-region, Angola and Zimbabwe, undermined the façade of continental consensus so much emphasized in the diplomatic rhetoric of SA.

One example of where this conjectured unity scuppered a viable multilateral strategy was in the matter of Security Council reform. The UN's 60th anniversary World Summit during 2005 was preceded by unprecedented worldwide hopes for

\footnotetext{
${ }^{30}$ G8, Africa Action Plan, www.g7.utoronto.ca/summit/2002kananaskis/africaplan.html

${ }^{31}$ Speech by the Minister of International Relations and Cooperation on "South Africa's foreign policy focus today and in the future" at the University of the Free State, Bloemfontein, 30 March 2010. http:// www.dfa.gov.za/docs/speeches/mashabane.html

${ }^{32}$ Spies, "Multilateral maze".

${ }^{33}$ Kotzé, "Identity and international dynamics".
} 
structural reform ${ }^{34}$ in this epitome of unrepresentative global governance, which allows a small, exclusive club of states to wield de facto as well as de jure power over the fate of mankind. Africa positioned itself for a breakthrough in joining the Council, spurred on by the distinction of being the only continental bloc that had articulated a 'Common Position' on Security Council reform. The AU's Ezulwini Consensus of 2005 demanded two permanent African seats, endowed with veto powers, on a reformed Council. Unfortunately, the continent's multilateral strategy proved to be too rigid and the artificial consensus unravelled when the AU engaged in negotiations with other reform coalitions. Its bid failed, and with it the very real prospect of a permanent seat for SA was lost. ${ }^{35}$

Apart from its multilateral attempts to transform the structure of the Security Council, SA also took issue with the Council's mandate, specifically its encroachment on the jurisdiction of the General Assembly. In this regard, it supported the African and broader South contention that the Assembly should occupy the "central role and position as the chief deliberative, policy making and representative organ of the UN in all matters, including those relating to international peace and security". ${ }^{36}$ During a controversial two-year (2007/08) stint - its first ever - as non-permanent Security Council member, SA actively subverted the political hegemony of the Council. It advocated the sovereign right of states to conduct their domestic affairs without interference, but its voting behaviour attracted accusations that it was defending rogue behaviour among "comrade states" in the global South, and Africa in particular. It seemed as if SA was increasingly sacrificing its foreign policy reputation on the altar of blind ideological allegiance, undermining the ostensible normative foundation of its multilateralism by placing a higher premium on solidarity than on morality - a tendency among developing states against which Deon Geldenhuys ${ }^{37}$ has cautioned.

SA's multilateralism had reached a crossroads: at the international level, its moral authority was waning, with the ideological as opposed to pragmatic-economic drivers of its multilateralism questioned not only by foreign observers, but increasingly by the domestic constituency as well. At the continental level, its African Renaissance project seemed less revered than it was by the rest of the international community. ${ }^{38}$ The new SA's honeymoon with the world had come to an end. ${ }^{39}$

\footnotetext{
${ }^{34}$ As proposed by Secretary General Annan in his 2005 report, In larger freedom.

${ }^{35}$ Spies, "Multilateral maze".

${ }^{36}$ NAM, Plan of Action: 2006 - 2009, par. 39.3. This position was also forcibly reiterated by Deputy Foreign Minister Aziz Pahad in his speech to SAIIA, February 2007. http://www.dfa.gov.za/docs/speeches/ pahad.htm

${ }^{37}$ Geldenhuys, "SA as norm entrepreneur", 101.

${ }^{38}$ Alden and Le Pere, "South Africa in Africa", 146-9.

${ }^{39}$ As Minister of International Relations and Cooperation Nkoana-Mashabane acknowledged during a lecture at Rhodes University in October 2009: "The era of being the toast of the world is over; we are now viewed and treated like any other country." http://www.dfa.gov.za/docs/speeches/mashabane.html
} 
A new era in the country's foreign policy dawned when his own party forced Mbeki from office in September 2008. His exit raised questions about the sustainability of SA's ideologically-driven multilateralism, something that warranted reconsideration in any case, in the light of systemic developments at the global level.

\section{Multilateralism in a polypolar world}

The post-bipolarity IR discourse has, as mentioned, entertained various successor scenarios, typically focusing on configurations of a multipolar system. Samuel Huntington has identified a combination of multi- and unipolarity that he refers to as "uni-multipolarity": a vertical structure of global power that is multi-tiered and hierarchical. ${ }^{40}$ The idea is supported by authors such as Barry Buzan and Ole Wæver, ${ }^{41}$ who posit that global power is increasingly regionally structured, with the hyperpower of the US being challenged not just by single-state powers such as China, but also by groups of states that are regionally organised, such as the EU. Most of the multipolar models that have been mooted have approached multipolarity from the state-centric perspective of traditional IR paradigms, even if acknowledging the impact of IGOs such as the UN and EU.

However, polarity that involves an IGO suggests a certain structural flexibility and unpredictability in global order, because membership of IGOs can and do overlap, expand or contract. 'Polarity' in Africa is also subject to the overlapping participation by states in regional integration schemes, and compounded by clashing loyalties incurred by extra-continental partnerships. A case in point is SA's membership of IBSA, which during 2005 rendered the country much more sympathetic to the aspirations of Brazil and India which, as members of the 'Group of Four', ${ }^{42}$ submitted a separate model for Security Council reform. The model was sufficiently close to the AU's Common Position to fuel expectations that a joint position could muster majority support in the General Assembly, prompting the two multilateral groups to engage in negotiations. SA, along with only a minority of other African states, was willing to make the required compromises and the joint position therefore failed to materialise.

SA's membership of IBSA has since been affected $^{43}$ by another overlapping bloc - that of the Brazil-Russia-India-China (BRIC) ${ }^{44}$ quartet, which was launched at summit level during June 2009. The four BRIC members seem to position

\footnotetext{
${ }^{40}$ Huntington, "The Lonely Superpower".

${ }^{41}$ Buzan and Wrver, Regions and powers.

${ }^{42}$ Brazil, Germany, India and Japan.

${ }^{43}$ Kornegay, Will a BRIC fall on IBSA?

${ }^{44}$ Goldman Sachs coined the acronym BRIC in 2003, and identified the four countries as having the economies with the greatest development potential on the basis of positive economic fundamentals, large and growing populations, and the ability to exploit resource assets, such as oil.
} 
themselves as a new power pole - but have excluded SA, despite the fact that the latter's foreign policy prioritises Brazil, India and China for strategic partnerships. ${ }^{45}$ Whereas the partners in IBSA share SA's global South commitments to the reform of global governance, BRIC straddles the North-South divide and does not seem to have any normative agenda, but rather a purely economic, some would say mercantilist, focus. ${ }^{46}$

One of the IBSA members (India) and three of the four BRIC members (Russia, India and China, all of which are nuclear powers) are also associated with another powerful and recently formed bloc: the Shanghai Cooperation Organisation (SCO), established in 2001. The SCO is comprised of some of the world's largest energy producing and exporting nations, and almost half of the global population. ${ }^{47}$ Like BRIC, it also operates without the burden of an ideological mission. The profile of global power distribution is evidently more complex than implied by classical interpretations of multipolarity. Moreover, the reality of 21 st century politics is eroding the 'one-size-fits-all' Westphalian model of state sovereignty. New powers include not only geopolitical nodes, but also non-state actors such as non-governmental organisations (NGOs), multinational companies (MNCs) and even sub-national entities. The fact that these actors are challenging the preeminence of states is a reality that demands a more sophisticated interpretation of the distribution of global power. ${ }^{48}$

An appropriate label for a global power constellation characterised by fluidity and transience of poles, may be 'polypolarity'. ${ }^{49}$ This would imply that power is becoming more mobile and situational, and that the various centres of gravity are not necessarily mutually exclusive. Rather than having distinct tiers of power, in a polypolar world tiers are also situational. The hierarchical models proposed by Buzan and Wrever, or Huntington for that matter, may therefore be entirely valid - but on an ad hoc basis. Haass, who uses the term 'nonpolarity', makes the point that power and influence are less and less linked in the new global order. The implications for large and small powers alike are significant. Geoffrey Wiseman argues that even the US has had to acknowledge that its uncontested hard power in international relations is simply not sufficient to succeed in its

\footnotetext{
${ }^{45}$ First articulated in Resolution 8(23) of the African National Congress' 52nd National Conference, December 2007, and subsequently echoed in foreign policy statements of the South African government. See, for example, the lecture by the Minister of International Relations and Cooperation, NkoanaMashabane, at Rhodes University. Grahamstown, 22 October 2009. http://www.dfa.gov.za/docs/ speeches/mashabane.html

${ }^{46}$ Shaw et al. ("Emerging powers and Africa", 32) assert that the BRIC countries all use soft power to promote their national interest.

${ }^{47}$ De Haas, "Time for EU and NATO", 43.

${ }^{48}$ Haass, "Age of nonpolarity", 44.

${ }^{49}$ Caution is required: in the extreme sense of the word, polypolarity could imply a paradox in that poles would be considered randomly interchangeable. This is obviously not (yet) the case in a global system where the sovereignty of states continues to be the bedrock of international law.
} 
foreign policy goals. ${ }^{50}$ It finds the pressure of contemporary diplomatic culture, with its pervasive norms of multilateralism and transparency, ever more difficult to shun.

The lack of "more predictable fixed structures and relationships that tend to define worlds of unipolarity, bipolarity, or multipolarity", ${ }^{51}$ Haass contends, poses great challenges to diplomacy. It also increases the need for innovative multilateralism to deal with transnational concerns. Various approaches include the use of associative diplomacy, ${ }^{52}$ where one or more actors is an IGO, and the use of informal groups. The latter includes state-centric groups, such as the Six-Party Talks on North Korea, and combinations of states and IGOs, such as the Quartet on the Middle East. These smaller groups are more flexible, and often revolve around personal networks - very much mirroring the African multilateral tradition. It would follow that semi-peripheral middle powers such as South Africa, by virtue of their proactive multilateral inclination, are therefore in a sense welladapted to navigation in a polypolar world.

The control of the major powers, according to Haass, is eroded by globalisationdriven interdependence. More and more issues on the global diplomatic agenda are falling within the 'jurisdiction' of global governance, meaning that polypolarity will stimulate rather than inhibit the demand thereof. In an uncertain structural environment, global governance becomes a safety net. The fact that human concerns increasingly exist on a global, horizontal axis, disconnected from the essentially vertical state structure, makes it difficult for individual governments, even for supranational organisations, to address such problems effectively. Jordaan observes that the influence of transnational issue networks has thus been on the rise as they usurp many of the roles traditionally performed by middle powers, thereby "acting as the conscience of a global civil society". ${ }^{53}$

Within the literature, several commentators have identified the development of a symbiosis between state and non-state actors, manifesting in so-called "polylateral diplomacy". Wiseman explains that it has become imperative for traditional, statecentric diplomacy "to be complemented with explicit awareness of a further layer of diplomatic interaction and relationships". ${ }^{54}$ This has resulted in the growth of new, unconventional forms of cooperation and international agreements. ${ }^{55}$ Examples include the lobbying of the International Campaign to Ban Landmines, which resulted in the 1997 Ottawa Convention on the Probibition of the Use, Stockpiling, Production and Transfer of Antipersonnel Mines. The involvement of civil society in

\footnotetext{
${ }^{50}$ Wiseman, "Pax Americana".

${ }^{51}$ Haass, "Age of nonpolarity", 44.

${ }^{52}$ Barston, Modern diplomacy. Chap. 3.

${ }^{53}$ Jordaan, "Concept of a middle power", 170-1.

${ }^{54}$ Wiseman, "Polylateralism and New Modes", 37.

${ }^{55}$ Barston, Modern diplomacy, Chap. 3.
} 
the delivery of global public goods offers a legitimising, democratic element to the work of governments.

\section{Rethinking South Africa's multilateral strategies}

The challenge for SA is to adapt its multilateral strategies to the changes in global power relations. As a start, it needs to reconsider its naïve insistence on African consensus. Denying not just the existence but also the utility of factional coalitions within the continent has moulded SA's multilateralism, especially as concerns political issues such as UN reform, into a diplomatic strait-jacket. Since the advent of the presidency of Jacob Zuma in May 2009, the country's foreign policy rhetoric has however displayed a subtle shift in this regard. Consolidation of the African Agenda is still punted as a key objective, ${ }^{56}$ but for the first time since SA's transition to democracy, the precedence of 'national interest' is being broached.

In October 2009, Foreign Minister Nkoana-Mashabane reiterated SA's aspiration to assume a permanent Security Council seat, without so much as a passing reference to Africa's 'common position'. ${ }^{57}$ In the same speech, she also played down the notion of elevating the AU's authority to that of a supranational entity. In December 2009, SA did notably less than usual in seeking African consensus at the UN Framework Convention on Climate Change in Copenhagen. After protracted negotiations, a last-ditch compromise was devised by the US, China, India, SA and Brazil. The contents of the proposal provoked a heated diplomatic stand-off, with the leader of the G77 group, Sudanese Ambassador Lumumba Di-Aping, accusing SA of betraying Africa's interests. ${ }^{58}$ Commentators are beginning to speculate, as Siphamandla Zondi puts it, that SA may be setting aside its idealism in favour of "a realistic perspective on its conduct of international relations". 59

Rather than deny its obvious hegemony in Africa, SA should embrace the advantages as well as responsibilities that are implied by this status. Habib and Selinyane argue that SA, on account of its aggregate economic, diplomatic, and military capabilities in relation to the rest of the continent, is destined to provide a political and socio-economic vision of its transnational environment, on the understanding that "if that vision is one of security, stability and development ... [it will]

\footnotetext{
${ }^{56}$ Address by South African President Jacob Zuma on the occasion of the Presidency budget vote for 2010/ 2011. Cape Town, 12 May 2010. http://www.dfa.gov.za/docs/speeches/jzuma.html

${ }^{57}$ Lecture by the Minister of International Relations and Cooperation at Rhodes University, Grahamstown, 22 October 2009, http://www.dfa.gov.za/docs/speeches/mashabane.html http://www.dfa.gov.za/docs/ speeches/mashabane.html

${ }^{58}$ BBC News, "Copenhagen deal reaction in quotes", 19 December 2009. http://news.bbc.co.uk/2/hi/ science/nature/8421910.stm. Note that Di-Aping later apologised for his tone.

${ }^{59}$ Zondi, "Contributing the South African perspective", 29.
} 
undertake to underwrite the implementation of these goals". ${ }^{60}$ In the Gramscian tradition, hegemony can thus have legitimacy if it implies the consent of the subordinates or governed. Alden and Le Pere, noting the work of critical theorists such as Cox, assert that SA'n hegemony can be effective if reified through the construction of collectively useful institutions in the region. This would also require a leadership role that SA has evaded thus far, namely moral guidance vis-à-vis the continent. ${ }^{61}$ Normative notions associated with middle power status, such as pivotal responsibilities, partnership, multilateralism and moral leadership, are thus entirely compatible with hegemonic status.

A new forum in which SA is bound to weigh national versus continental interest is the G20. The latter supplanted the G8+5 when, at its September 2009 Pittsburgh Summit, it formally became the successor to the G8 as engine of the global economy. ${ }^{62}$ While this is a more representative forum of global economic and financial governance, SA is the only African member state, and it may be unrealistic, if not unethical, for SA to distance itself from its representation of broader African interests. However, the country needs to delink its foreign policy from purely ideological associations, which create unrealistic foreign policy expectations and waste the country's already over-stretched diplomatic resources.

Recent foreign policy rhetoric confirms that SA still sees itself as a champion of the global South, ${ }^{63}$ but it could learn some tactical lessons from its 'strategic' South-South partners: they are all engaging in assertive economic diplomacy to ensure that they become (part of) a new power pole. As Shaw et al. declare: "the rapid and steady intrusion and recognition of a set of major emerging economies is challenging the established order, wrenching global relations into flux...these countries seek a reorientation of power towards multipolarity". "64 SA's policymakers have admitted that the country is in dire need of more economic diplomatic expertise to the extent that this goal was articulated in President Zuma's first 'five year' strategic plan. ${ }^{65}$

The harsh reality is that the SA'n economy, while dominating Africa, is rather insignificant in global terms, hence its exclusion from BRIC. The government has not admitted that it felt slighted by its omission, but it has evidently embarked on a diplomatic campaign to secure an invitation to the BRIC table: having already visited Brazil at head of state level, ${ }^{66}$ President Zuma (who is known to be less enamoured of the red carpet circuit than his predecessor was) undertook a

\footnotetext{
${ }^{60}$ Habib and Selinyane, "Constraining the unconstrained", 181.

${ }^{61}$ Alden and Le Pere, "South Africa in Africa", 148.

${ }^{62}$ G20 Pittsburgh Summit, Leaders' Statement, 24-25 September 2009, http://www.g20.org/Documents/ pittsburgh_summit_leaders_statement_250909.pdf.

${ }^{63}$ Kornegay, Will a BRIC fall on IBSA?, 1.

${ }^{64}$ Shaw et al., "Emerging powers and Africa", 27.

${ }^{65}$ SA Presidency, Medium Term Strategic Framework.

${ }^{66}$ Zuma paid a state visit to Brazil in October 2009 and the visit was reciprocated by President Luiz Inacio Lula of Brazil in July 2010.
} 
marathon of state visits to New Delhi, Moscow and Beijing in the three-month period June to August $2010^{67}$ - notwithstanding SA hosting the FIFA World Cup, and dozens of soccer-loving heads of state and government, right in the middle of this period! ${ }^{68}$

Worryingly, though, SA is lagging not just in terms of current economic performance, but also in potential, which explains why it has not been included in the next projected tier of emerging economies, the BRIC successors known as the Next-11. ${ }^{69}$ The group comprises developing as well as newly industrialised economies, and includes two African countries, Nigeria and Egypt. Of note for SA is that these two states happen to be its strongest (and officially declared) African contenders for a permanent Security Council seat. According to Shaw et al., the emerging powers included in BRIC and the Next-11 are the new "global middle" which "is already giving rise to the reordering of actual global relations and highlighting the need to rethink definitions and practices of global governance". The same authors note that emerging power status will depend inter alia on whether a state has "the ability to identify and advance new international priorities as well as an alternative agenda for international cooperation". ${ }^{70}$

The scope of this article does not allow for discussion of the economic remedies that are required if SA wants to avoid being relegated to a new global periphery. However, an obvious economic advantage in terms of its multilateral strategising is the fact that the country offers a gateway ${ }^{71}$ to a huge, resource rich continent. It is instructive that in a June 2010 speech to business leaders at the G20, President Zuma wasted no time in advertising SA's extended economic backyard by stating that "Africa offers a huge market of one billion people and provides enormous economic potential. Sub-Saharan Africa is the third fastest growing region in the world, after China and India". ${ }^{72}$ At a political level, SA offers a similar gateway to a continent that has more members of the UN General Assembly - read vote-wielding entities - than any other region. This means that SA can vie for inclusion in global power blocs on account of "its representational role as a regional power". ${ }^{73}$

\footnotetext{
${ }^{67}$ Register of state visits undertaken by and scheduled for Jacob Zuma contained in websites of the SA Presidency (http://www.thepresidency.gov.za/) and the Department of International Relations and Cooperation (http://www.dfa.gov.za/).

${ }^{68}$ The FIFA Soccer World Cup was hosted by SA from 11 June to 11 July 2010.

${ }^{69}$ Identified by Goldman Sachs in 2005, as Bangladesh, Egypt, Indonesia, Iran, South Korea, Mexico, Nigeria, Pakistan, the Philippines, Turkey and Vietnam.

${ }^{70}$ Shaw et al., "Emerging powers and Africa", 29 and 35.

${ }^{71}$ In a speech during his state visit to Russia, President Zuma stated as much: "As South Africa, we are strategically located on the southern tip, as a gateway to the rest of the continent." (Official opening of the talks between the South African and Russian Federation delegations on the occasion of the official visit by South African President Jacob Zuma, Moscow, 5 August 2010, http://www.dfa.gov.za/docs/speeches/ jzuma.html).

${ }^{72}$ Address by South African President Jacob Zuma to G20 business leaders on partnering with Africa's dynamic markets, Toronto, 24 June 2010, http://www.dfa.gov.za/docs/speeches/jzuma.html. In his speech, he referred to the continent 53 times, while mentioning SA only seven times.

${ }^{73}$ Shaw et al., "Emerging powers and Africa", 36.
} 
Critics will see in such a diplomatic strategy a mercenary attitude towards the rest of the continent, but SA would be foolish not to exploit this geopolitical cum geoeconomic advantage.

Beyond its obvious African credentials, SA should position itself as a strategic partner to emerging or fluctuating power poles by resorting to its inventory of political comparative advantages in the multilateral domain. Its most authoritative, if recently tarnished, asset is its status as middle power: in other words, its ability to act as 'bridge', 'broker' or 'gate-keeper' in the corridors of global power.

SA will however benefit from a more selective, ad hoc approach than it has thus far adopted in its multilateral projects. In March 2010, the foreign minister proclaimed, "Our foreign policy remains firmly anchored on the African continent and the developing countries of the world," 74 but the reality is that SA lacks the political as well as economic resources to service an ideological marriage to a group of states as large and diverse (and often with clashing foreign policy objectives) as the global South. Nor can it sustain a 'generalist' middle power role, and therefore specialisation in certain areas is called for. This will save resources while simultaneously allowing for a higher profile in select areas. One of these is conflict resolution. Ironically, conflict-ridden Africa has provided SA the opportunity to develop impressive credentials in the field of mediation and peacekeeping. This is a niche area of the country's diplomatic endeavours, guarantees moral stature at the global level and should be projected to maximum effect for 'specialist state' recognition in multilateral fora. By the same token, SA's expertise in other niche areas of diplomacy, notably disarmament and lately even climate change, should be utilised to consolidate its middle power credentials.

A more focused multilateral role will require rationalisation of foreign policy priorities. In establishing these, the government could draw on the expertise and "new policy ideas widely available in global civil society" 75 by ensuring closer cooperation with transnational issue networks. The latter, Jordaan points out, are impacting on the role of middle power internationalism because they are better at stimulating bottom-up change in terms of transnational normative action. ${ }^{76}$ SA has some experience of such polylateral diplomacy, including as mentioned the Ottawa Process and the establishment of the International Criminal Court. A more recent example is the Kimberley Process, which sought to clamp down on the lucrative trade in 'conflict (or 'blood') diamonds', a catalyst in many of Africa's intractable conflicts. SA took a leading role in this process which resulted in the 2003 certification scheme.

\footnotetext{
${ }^{74}$ Speech by the Minister of International Relations and Cooperation on "South Africa's foreign policy focus today and in the future" at the University of the Free State, Bloemfontein, 30 March 2010. http://www.dfa.gov.za/docs/speeches/mashabane.html

${ }^{75}$ Wiseman, "Polylateralism and New Modes", 51.

${ }^{76}$ Jordaan, "Concept of a middle power", 170.
} 
The implications of a more integrated, strategic approach to SA's middle power role will require redefinition of the stakeholders in foreign policy formulation and implementation, and the creation of mechanisms to ensure their optimal engagement. The foreign ministry has taken tentative steps in this direction by reaching out to the South African academic community - a relationship that had soured as a result of the intellectual arrogance and centralisation of foreign policy that characterised the Mbeki presidency. During a 'road-show' to a series of South African universities, Foreign Minister Nkoana-Mashabane acknowledged that "think-tanks and universities have a critical role to play in generating ideas and options for South African foreign policy". This outreach initiative is commendable and needs to be broadened as well as widened to the many stakeholders of SA's foreign policy.

Another challenge for the South African government will be the recruitment, training and deployment of civil servants (all the de facto diplomats who are tasked with SA's international relations) who are competent to build SA's middle power image through bilateral, multilateral as well as polylateral engagement. As Andrew Cooper, Brian Hocking and William Maley note, diplomats are not traditionally trained for a role in global governance, because diplomacy is considered an exclusive activity whereas "global governance, by contrast, is an open-ended way of looking at and navigating in the world, with a high degree of inclusiveness about whom and what is included in its machinery and agenda". ${ }^{77}$

\section{Conclusion}

Coinciding with the end of the bipolar Cold War, SA's peaceful democratic transition thrust the country into the spotlight of a world in flux. The new SA's willingness to commit resources to international peace processes and to 'punch above its weight' in global governance fora soon bestowed on it disproportionate clout in multilateral institutions. Within a few years its exemplary behaviour in the global arena had earned the country a reputation as a middle power. However, it also adopted an increasingly strident ideological approach in its foreign policy rhetoric, insisting on structural change in global governance. Championing the cause of the global South seemed fitting initially, given SA's political history, its developmental challenges and the fact that the immediate post-Cold War ideological axis and power discourse changed from West-East to North-South. SA's multilateral inclination to prioritise the legitimacy rather than the efficiency of global governance distinguished its middle power role from that of its counterparts in the global North and, notwithstanding a track-record of norm entrepreneurship, its government began to attract criticism that it was sacrificing human rights principles for the sake of ideological solidarity in multilateral institutions. Although SA has not

${ }^{77}$ Cooper et al., Global Governance and diplomacy, 1. 
deviated from the norms of global diplomatic culture, its zeal to transform global governance has seen the form of multilateral fora (such as the Security Council) elevated above the substance of their agenda (such as human rights). This has arguably diluted the normative premises of its multilateralism.

At the continental level, SA has been instrumental in remarkable institutional transformation and the entrenchment of the African Agenda in the global governance arena. Despite its glaring economic dominance of, and some critics allege predatory behaviour on, the continent, the country has thus far stifled its natural political leadership profile in Africa, insisting on and abiding by collective decision-making, as though hegemony and the pursuit of regional public goods amount to mutually exclusive foreign policy options. SA's assertive diplomacy in global governance fora ensured its acquisition of influence disproportionate to its economic clout, but at the continental level, the reverse has been true. Ironically, Africa's robust microcosm of the global struggle to redefine power relations has exposed the fault-lines in SA's coy multilateral political strategy vis-à-vis the continent.

At the global level, SA's prioritisation of South-South coalitions is appearing increasingly unrealistic. The various emerging powers that it has identified as 'strategic partners' - countries such as China, Brazil and India - are engaging in new multilateral formations with narrower, issue-driven agendas. The blocs are dynamic, overlap and ignore the North-South division, revealing a 'new middle' of global politics. Significantly, these states pursue an economic rather than ideological foreign policy agenda.

Unless it reconsiders the rigid global South solidarity in its multilateral strategies, SA is at risk of being relegated to a new global periphery. It cannot compete with the economic powers of the world, but the emerging polypolarity of global power relations is offering distinct opportunities for tactical diplomatic initiatives and niche diplomacy. In a world where centres of gravity are overlapping and transient, power is becoming situational. Norms of global diplomatic culture are rendering diplomatic joint ventures, both state and non-state centric, an imperative and transnational interdependence are inserting human security concerns on the diplomatic agenda of big and small powers alike.

SA has the geopolitical advantage of being a regional power and this gateway status can be exploited at the economic as well as political level. Over and above this, the country is already considered a multilateral 'specialist'. Central to its success will be its ability to de-ideologise and rationalize its multilateralism. If it focuses on its comparative advantages in the international arena, specifically its specialisation in human security areas such as conflict resolution and climate change, the pragmatic as opposed to normative drivers of its multilateralism need not be approached as a zero-sum choice. As a leaner, more supple (and perhaps more honest) middle power - shed of ideological weight - SA will have 
ample opportunity to impact the fora where power is wielded: the institutions of global governance.

\section{References}

African National Congress. Resolutions of the 52nd National Conference. Polokwane, 16-20 December 2007.

Alden, A. and G. Le Pere. "South Africa in Africa: bound to lead?" Politikon 36, no. 1 (April 2009): 145-69.

Annan, K. In larger freedom: towards development, security and human rights for all. Report of the Secretary-General prepared for the General Assembly's Millennium+5 Summit. New York, 21 March 2005.

Barston, R. P. Modern diplomacy. (3rd ed). London: Longman, 2006.

Bond, P. Talk Left, Walk Right: South Africa's frustrated global reforms. (2nd ed). Pietermaritzburg: University of KwaZulu-Natal Press, 2006.

Buzan, B. and O. Wæver. Regions and powers: the structure of international security. Cambridge: Cambridge University Press, 2003.

Cooper, A.F, B. Hocking and W. Maley. Global Governance and diplomacy: worlds apart? London, New York: Palgrave Macmillan, 2008.

De Haas, M. "Time for the EU and NATO to engage with the Shanghai Cooperation Organisation". Europe's World. Autumn 2008 No.10: 43-7. http://www.europesworld.org/portals/0/ PDF_version/EW10_FINAL_ENG.pdf

Fukuyama, F. "The End of History?” The National Interest. (Summer 1989).

G8. Africa Action Plan, adopted by the Summit of the Heads of State and Government of the G8. Kananaskis, 27 June 2002. www.g7.utoronto.ca/summit/2002kananaskis/africaplan.html

Geldenhuys, D. "South Africa's role as international norm entrepreneur". In In Full Flight: South African foreign policy after apartheid, edited by W. Carlsnaes and P. Nel: 97-106.

Midrand: Institute for Global Dialogue, 2006.

Haass, R.N. "The Age of Nonpolarity: What will follow US dominance". Foreign Affairs 87, no. 3 (May/June 2008): 44-56.

Habib, A. "South Africa's foreign policy: hegemonic aspirations, neoliberal orientations and global transformation". South African Journal of International Affairs 16, no. 2 (August 2009): 143-59.

Habib, A. and N. Selinyane. "Constraining the unconstrained: civil society and South Africa's hegemonic obligations in Africa”. In In Full Flight: South African foreign policy after apartheid, edited by W. Carlsnaes and P. Nel: 175-81. Midrand: Institute for Global Dialogue, 2006.

Huntington, S.P. "The lonely superpower". Foreign Affairs 78, no. 2 (March/April 1999).

Jordaan, E. "The concept of a middle power in international relations: distinguishing between emerging and traditional middle powers". Politikon 30, no. 2 (November 2003): 165-81.

Kornegay, F. South Africa's South-South Dilemmas: Will a BRIC fall on IBSA? Global Insight Series 88. Midrand: Institute for Global Dialogue, July 2009.

Kotzé, D. "Identity and international dynamics: South Africa's state identity". Paper delivered at the AISA/SAAPS research symposium: "Defining the contours of knowledge production in the 21 st century", Pretoria, 15 October 2009.

Mandela, N. "South Africa's future foreign policy". Foreign Affairs 72, no. 5 (Nov-Dec 1993): 86-97.

Muller, M.E. "Current events in South African diplomacy". In Modern diplomacy, edited by J. Kurbalija: 179-210. Malta, Belgrade, Geneva: Diplopublishing, 1998. 
Non-Aligned Movement. Plan of Action: 2006 - 2009. Adopted by the XIV Summit of Heads of State or Government of the NAM. Havana, 11-16 September 2006. http://www.namegypt.org/ en/RelevantDocuments/Pages/default.aspx

Puchala, D.J. "Third World thinking and contemporary International Relations". In International Relations theory and the Third World, edited by S.G. Neuman. London: Macmillan, 1998.

Serrão, O. and P. Bischoff, "Foreign policy ambiguity on the part of an emergent middle power: South African foreign policy through other lenses". Politikon 36, no. 3 (December 2009): 363-80.

Shaw, T.M, A.F. Cooper and G.T. Chin. "Emerging powers and Africa: Implications for/from global governance?” Politikon 36, no. 1 (April 2009): 27-44.

South Africa, Republic of. The Presidency. "Together, doing more and better: A framework to guide Government's programme in the electoral mandate period 2009-2014". Medium Term Strategic Framework, July 2009. www.thepresidency.gov.za/docs/pcsa/planning/mtsf_july09.pdf

Spies, Y. "The multilateral maze and (South) Africa's quest for permanent United Nations Security Council representation”. Strategic Review for Southern Africa XXX, no. 1 (May 2008): 96-122.

Van der Westhuizen, J. "Pretoria and the global conference circuit: hot air or hot stuff?," In In Full Flight: South African foreign policy after apartheid, edited by W. Carlsnaes and P. Nel: 137-46. Midrand: Institute for Global Dialogue, 2006.

Wiseman, G. "Pax Americana: bumping into diplomatic culture". International Studies Perspectives Vol. 6 (4) (2005): 409-30.

Wiseman, G. "'Polylateralism' and new modes of global dialogue”. In Diplomacy III, edited by C. Jonsson and R. Langhorne: 36-57. London: Sage, 2004.

Zondi, S. "Contributing the South African perspective". In Does Fairness Matter? edited by H. Altinay. Global Economy and Development Working Paper 40. Washington DC: Brookings Institution, April 2010. 